\title{
Does the Monitoring Mechanisms Considered as Dilemma against the Practices of Earnings Management
}

\author{
Dea'a Al-Deen Omar Al-Sraheen ${ }^{1}$, Isam Hamad Saleh ${ }^{1}$ \\ ${ }^{1}$ Department of Accounting, College of Business, Al-Zaytoonah University of Jordan, 11733, Amman, Jordan \\ Correspondence: Dea'a Al-Deen Omar Al-Sraheen, Department of Accounting, College of Business, \\ Al-Zaytoonah University of Jordan, 11733, Amman, Jordan.
}

Received: June 26, 2017

doi:10.5539/ibr.v10n10p39
Accepted: August 22, 2017

Online Published: September 7, 2017

URL: https://doi.org/10.5539/ibr.v10n10p39

\begin{abstract}
This paper mainly aims to explore the role of monitoring mechanisms in limiting the earnings management practices among service firms in Jordan. The data used in this study were from the financial annual reports of 59 ASE listed service firms in 2015. The results of multiple regression analysis demonstrate the fairly varied influence of board of directors' variables. This paper presented three hypotheses covering board independency, CEO duality and audit committee. According to the results, internal monitoring mechanisms significantly impact the level of the practices of earnings management and the reduction of the agency conflict. Additionally, the regulatory bodies in Jordan should focus more on the role of internal monitoring mechanisms in Jordanian companies in terms of effectiveness in order to improve the quality of financial reports can be improved via the assurance of high quality of earnings. Finally, this study becomes a catalyst for more research on quality of financial reports and earnings quality in Jordan and other countries where there is still lack of studies in this domain.
\end{abstract}

Keywords: earnings management, CEO duality and audit committee

\section{Introduction}

The financial reports' users have become cautious and skeptical about the financial statements particularly in terms of quality following the cases of reporting irregularities and unacceptable accounting practices of WorldCom and Enron in the U.S.A, and of One.Tel, HIH Insurance Harris Scarfe in Australia. The financial information provided in the financial statements is a primary source for investors in making decisions and these cases have robbed their confidence on information reliability that the listed firms provide (Liu, 2012).

Accounting alternatives are believed by many to enable corporate managers to opportunistically manage earnings and this may impart adverse impact on the quality of reported earnings and their application in the decision making process (Khalil \& Ozkan, 2016). Many explanations have been offered by past studies as to the reason the corporate managers may have the inclination to be manipulative in reporting the earnings. As suggested, corporate managers seek to earnings management practices for attaining some capital market and contractual objectives. These include evading debt covenants violation, raising their compensation share, fulfilling or going beyond the expectations of analysists and also, smoothing the reported earnings (Abed, Al-Badainah \& Serdaneh, 2012; Al-Sraheen, 2016)

It is common for the practices of earnings management to lead to grave corporate fraud. For instance, the subprime mortgage crisis that happened in 2007 caused grave crisis to the world economy while established firms including Lehman Brothers and Merry Lynch were pushed into bankruptcy owing to the managers' practice of earnings management. As stated by Lin and Wu (2015), these events have harmed firms' financial structure and the global economy. Also, the incidences of bankruptcy among globally established companies have shown how valuable corporate governance is. Many countries have imposed many laws to fortify the corporate governance mechanisms (the Sarbanes-Oxley Act of 2002 in the United States is among of the critical steps to attained improved quality of financial statements) (Lin \& Wu, 2015). In the context of Jordan, since 2009 , its regulatory authorities have also imposed many principles to reinforce corporate governance mechanisms. This, according to Al-Sraheen (2016) and Mohammad, Wasiuzzaman and Nik (2016), is as precautionary steps for dealing with risks of corporate bankruptcy. 


\section{Hypotheses Development}

This section comprises a review on the past literature linked to the independent variables and its role in the determination of the dependent variable using a logical hypothesis according to the past research's outcomes.

\subsection{Board Independence}

The board members are mainly responsible in monitoring and guiding top management as assurance that they are acting on behalf of stakeholders (FRC, 2012). A common believe is that directors on the board that are independent can provide guidance and monitoring to corporate managers in more effective manner. The primary reason for this is because independent directors have no involvement with firms' daily issues. For that reason, they have the capacity to effectively contribute in providing more objective feedback about the corporate performance and its financial operations (de Villiers, Naiker \& van Staden, 2011).

However, there are those who view that the firms' internal directors that have direct connection with the firms' agents are more inclined to be perceived as "creatures of the CEO" that are primarily accountable for legitimizing the decisions made by top executives. As such, preserving a larger number of independent directors will compel the board of directors to challenge the top managers and give assurance of a higher degree of effective monitoring (Liao, Luo \& Tang, 2015).

Agency theory posits that separation of managers and ownership causes a divergence in pursuing the interest of managers as opposed to that of owners. This is why the monitoring function is crucial for boards of directors as assurance of the protection of the shareholders' interests. Also, having boards that are controlled by independent directors may help curb the agency conflict. This is done via controlling and monitoring the corporate managers' opportunistic behavior. Consequently, Frankel, McVay and Soliman (2011), independent directors on the board may significantly contribute in the monitoring of the construction of financial reports by the management.

In short, it is affirmable that past research supports the hypothesis that high percentage of independent outside directors on the board clearly contributes in controlling the practices of earnings management (Alves, 2014). This implies that independent directors cause improvement of the level of earnings quality by reducing the earnings management's level. As such, the research hypothesis below will be tested:

$H \mathrm{H}$ : The presence of independent directors in the board contributes in decreasing the level of earnings management

\subsection{CEO Duality}

Separation of duties between the chairman of the board of directors and CEO has been reported to offer more independence to the board via reducing the effect of the CEO on the board. According to agency framework, the firm's board's capacity to practice its monitoring function loses its strength when the COB and CEO positions are held by the same individual, primarily due to power concentration (Liu, 2012). It is therefore expected that having the chair of the board who is also the CEO this will cause negative impact on the board's capacity in monitoring the performance of senior management efficiently and also the process of decision making. Therefore, Khalil and Ozkan (2016) expect that CEO duality will impart positive influence on earnings management practices.

Davidson, Goodwin-Stewart and Kent (2005) found no significant negative linkage among an independent chairman of the firm and earnings management. According to the authors, this may be caused by inadequate supervision by the board itself and non-executive chairperson because these parties are mostly not subject to corporate management (Chen, Luo, Tang \& Tong, 2015). It has been argued that it is likely that decreased influence of the $\mathrm{CEO}$ on the board can limit earnings management practices because of the outsiders' effective role of monitoring. Thus, the second hypothesis will be tested:

H2: The separation of the CEO and chairman duties is linked with a lower level of earnings management practices.

\subsection{Audit Committee}

Audit committee is a sub-committee of the board of directors. Audit committee primarily comprises non-executive directors and its creation is as an effective instrument for assuring the effective role of corporate governance within companies. An audit committee is describable as a sub-committee in the Board of Directors that manages the process of audit aside from functioning as a sub-committee of the Board (Hossain \& Khan, 2006).

In Jordan, the negative linkage between audit committees and earnings management may not hold owing to the presence of high level of concentrated ownership in Jordanian firms and also the ineffective public enforcement 
of fines, minority investor rights and weak sanctions by regulators (Najjar, 2016). As such, two major economic reforms are suggested to enable contradictory opportunities and incentives to monitor and control earnings management: cross-listing and assigning go vernment officials as audit committee members. According to Lin, Hutchinson and Percy (2015), an effective role of audit committee accomplishes its oversight function when it is not influenced by corporate management, has sufficient financial experience to perform its duties and provides active monitoring to internal controls functions and the process of financial reporting. As such, the third hypothesis below will be tested:

\section{H3: There is an effective role of audit committee in constraining earnings management practices.}

\section{Methods}

This study has chosen the ASE listed Jordanian companies as the research subjects because such firms abide by the rules and regulations of the Jordanian Code of Corporate Governance and the Listing Requirements. The ASE listed firms can be split into three sectors: industrial, services and financial sector. In this research, only the service sector listed on the Exchange for the year 2015 is selected as a research sample. There were 149 firms, 59 of which underwent the process of analysis. The process of data gathering includes collecting the financial and non-financial information presented in the annual financial reports of service firms as well from the website of ASE and of the firms.

\subsection{Measurements of the Research Variables}

The measurement of earning management employed the approach of accounting accruals of Jones' (1991) model which was revised by Dechow and Sloan (1996). The discretionary accruals (DA) are also termed as abnormal accruals and this method has been used by the past studies. The values of total accrual are split into discretionary accruals and non-discretionary accruals. In specific, discretionary accruals (DA) are for proving that corporate managers move corporate earnings from one period to another, allowing them easy manipulation of discretionary accruals. On the other hand, non-discretionary accruals comprise items of non-manipulated accounting accruals as managers cannot control these items.

The non-discretionary accruals (NDAC) value may be obtained from the discretionary accrual value (DAC) in the overall accrual. The method of obtaining the discretionary accrual (DAC) value is shown by the calculations below:

The total accrual value (TAC) is computable by the model below:

$$
\text { TAC }=\text { Net Income (NI) }- \text { Cash Flow from Operation (CF) }
$$

The non-discretionary accruals (ND) value and the discretionary accruals (DAC) value are computable via the insertion of the value of total accruals (TAC) into the equation of modified-Jones regression.

$$
\frac{T A C_{i t}}{T A_{i, t-1}}=a_{1}\left[\frac{1}{T A_{i, t-1}}\right]+a_{2}\left[\frac{\Delta R E V_{i t}-\Delta R E C_{i t}}{T A_{i, t-1}}\right]+a_{3}\left[\frac{P P E_{i t}}{T A_{i, t-1}}\right]+e_{i}
$$

Here, TACit denotes total accruals in year $t$; TA represents the lagged total assets for firm $i$; $\triangle$ REVit represents firm i's revenues change in year $t$ less revenue in year $t-1 ; \triangle$ ARit denotes the accounts receivable in year $t$ less accounts receivable in year t-1; PPEit represents firm i's gross property, plant and equipment in year $t$. Meanwhile, $\alpha 1-\alpha 3$ entail the regression parameters and e denotes equal error term.

The non-discretionary accruals are computable via the equation below:

$$
\frac{N D_{i t}}{T A_{i, t-1}}=a_{1}\left[\frac{1}{T A_{i, t-1}}\right]+a_{2}\left[\Delta \mathrm{REV}_{i t}-\Delta \mathrm{REC}_{i t}\right]+\mathrm{a} 3 \mathrm{PPE}_{i t}
$$

The value of discretionary accruals is computable with the equation below:

DACit $=$ TACit - NDACit

Note that, DAC denotes discretionary accruals; TAC denotes total accruals and NDAC denotes non-discretionary accruals.

Discretionary accruals of high values mirror the managers' opportunistic behaviour and this translates to earning of low quality. Thus, in this study, discretionary accruals of high level function as the earning management practices' indicator. The modified Jones model has been chosen in this study for earning management measurement because many past researches have proven the accuracy and robustness of this model in the 
computation of discretionary accruals when compared to other available models (Guay, Kothari, \& Watts, 1996; Abed, Al-Badainah, \& Serdaneh, 2012).

This study employed the multiple regression analysis in ascertaining the linkage between the board independence, CEO duality and audit committee and the earnings management. The following is the structural equation of the model:

$$
\mathrm{DAC}=\beta_{0}+\beta_{1} \mathrm{BIND}+\beta_{2} \mathrm{CEO}+\beta_{3} \mathrm{AC}+\varepsilon
$$

Note that:

DAC = The estimated discretionary accruals by the Modified Jones Model

BIND = Board independence measured by ratio of non-executive directors to the overall number of directors on the board,

$\mathrm{CEO}=$ Dichotomous variable as CEO Duality's metric; the combined roles of the CEO and chairman receives the score of 1 ; the score is 0 if otherwise

$\mathrm{AC}=$ Audit committee measured with dichotomous variable as a metric for this; company with an audit committee receives the score of 1 ; the score is 0 if otherwise

\section{Empirical Analysis}

\subsection{Descriptive Statistics and Correlations}

Table 1 presents the analyses of descriptive statistics for this study's variables. As denoted by the outcomes, firms' absolute value of earnings management receives a mean value of 0.0895 and a standard de viation value of 0.20114. Meanwhile, the values of earnings managements fall in the range of 0 to 1.02 which indicate fairly small deviation among companies. The outcomes also show clear involvement of service companies in Jordan in earnings management practices in their financial statements, such result is also supported by Ajeleh and Hamdan (2009) who documented that the $62 \%$ of Jordanian industrial firms involved in the earnings management practices.

Table 1. Descriptive Statistics

\begin{tabular}{cccccc}
\hline Variable & $\mathrm{N}$ & Minimum & Maximum & Mean & Std. Deviation \\
\hline EM & 59 & .00 & 1.02 & .0895 & .20114 \\
BIND & 59 & .27 & 1.00 & .6586 & .16421 \\
CEO & 59 & 0 & 1 & .46 & .502 \\
AC & 59 & 0 & 1 & .12 & .326 \\
\hline
\end{tabular}

This study employed the analysis of OLS regression to affirm if earnings management among service firms is significantly related with board independence, CEO Duality and audit committee. Prior to the process of analysis, the key assumptions of OLS regression were checked as assurance that no violations in regression assumptions were present. As can be seen in the correlation matrix between the independent variables presented in Table 2, there is no multicollinearity problem among independent variables. As can be seen, the highest level of correlation is between audit committee and CEO duality with $(r=0.127)$. Further, tests of homoscedasticity, normality and linearity assumptions are checked. This was to assure that these assumptions contain no violations.

Table 2. Correlations Matrix

\begin{tabular}{ccccc}
\hline Variables & EM & BIND & CEO & AC \\
\hline EM & 1 & .116 & .237 & $.358^{* *}$ \\
BIND & & 1 & -.015 & .051 \\
CEO & & & 1 & -.127 \\
AC & & & & 1 \\
\hline
\end{tabular}

4.2 Basic Regression Results

Table 3 comprises the OLS regressions outcomes for estimating the earnings management coefficient and checking the effects that the board independence, CEO Duality and audit committee on earnings management.

The research model that this study employed was very significant $(F=5.140$, Sig-Value $=0.003)$ with an adjusted $\mathrm{R}^{2}$ of $17.6 \%$. This demonstrates that the independent variables (board independence, CEO duality and audit committee) explained approximately $17.6 \%$ of the overall variation of the dependent variable (earnings management).

With respect to the first research hypothesis, board independence postulated the contribution of the independent directors in the board in decreasing the level of earnings management which consequently causes increase in firm's level of earnings quality. This finding contradicts with the anticipation that the association was positive 
but not significant. This result is also documented by previous research which reported that there is a negative and not significant relationship between board independence and earnings management as mentioned by Klein (2002). As such, H1 is not supported.

Table 3. The Result of OLS Regression Analysis

\begin{tabular}{|c|c|c|c|c|c|}
\hline & Unstan & efficients & $\begin{array}{c}\text { Standardized } \\
\text { Coefficients }\end{array}$ & & \\
\hline & $\mathrm{B}$ & Std. Error & Beta & $\mathrm{t}$ & Sig. \\
\hline (Constant) & -.073 & .102 & & -.713 & .479 \\
\hline BIND & .123 & .146 & .100 & .841 & .404 \\
\hline $\mathrm{CEO}$ & .115 & .048 & .288 & 2.396 & .020 \\
\hline $\mathrm{AC}$ & .240 & .074 & .389 & 3.234 & .002 \\
\hline Sig $=0.003$ & $\mathrm{~F}=$ & & $\mathrm{R} 2=17.6 \%$ & & \\
\hline
\end{tabular}

Conversely, there is positive and significant relationship between CEO and earnings managements. This demonstrates that the separation of duties between those of chairman of the board of directors and those of CEO can grant more capacity to the board in detecting and limiting the earnings management practices via reduction of CEO influence on the board. This outcome is in support to the second hypothesis which states that the separation of the duties of CEO and chairman has linkage with earnings management practices of lower level. In addition, a weak internal control environment has the potential to allow "intentionally biased accruals through earnings management" (Doyle, Ge \& McVay, 2007). Therefore, CEO domination is likely to create incentives for opportunistic earnings managemen. Chen \& Liu (2010) as well documented that the CEO-dominated firms are associated with higher likelihood of earnings management. Thus, this finding is in support to the second hypothesis.

Finally, there appears a positive and significant linkage between the presence of an audit committee in a firm and its role in controlling the practices of earnings management. This outcome is in support to the third hypothesis. Such result is strongly supported by (Xie, Davidson \& DaDalt, 2003) who reported that the audit committee members with corporate or financial backgrounds are related closely with companies that have smaller discretionary current accruals. As well, a frequency board and audit committee meeting is also related with decrease levels of discretionary current accruals.

\section{Conclusion and Future Research}

This research mainly aimed to examine the role of board independence, CEO duality and audit committee in controlling the earnings management practices among service firms operating in Jordan for year 2015. As the results demonstrate, there is practice of earnings management among service firms in Jordan in their financial reports. The results also show a positive role of separation between the duties of chairman of the board of directors and CEO and the presence of audit committee in limiting the earnings management practices. However, board independency and earnings management are not significantly linked.

This study is a valuable addition to the literature of earnings management and internal monitoring mechanisms because it presents proof that the internal monitoring mechanisms assist in controlling earnings management practices. However, this study did not cover some aspects that may have relevance to the internal monitoring mechanisms and earnings management. Thus, the forthcoming work should look into the moderating role of audit committee in controlling the adversity of the duality of duties among chairman of the board of directors and CEO, and the adverse impact that ownership concentration has on earnings management.

\section{References}

Abed, S., Al-Badainah, J., \& Serdaneh, J. A. (2012). The level of conservatism in accounting policies and its effect on earnings management. International Journal of Economics and Finance, 4(6), 78. https://doi.org/10.5539/ijef.v4n6p78

Ajeleh, I., \& Hamdan, A. (2009). The impact of Corporate Governance on Earnings Management: Evidence from Jordan. The international financial and economic crisis and global governance. Oct. 2009.

Al-Sraheen, D. A. A. D., \& Nawwaf, O. (2014). The relationship between corporate governance mechanisms and company attributes and accounting conservatism of Jordanian listed companies (Doctoral dissertation, Universiti Utara Malaysia).

Al-Sraheen, D. A., \& Khateb, K. (2016) Proposing model for limiting Earning Management practices: Case of Jordanian Listed Firms Corporate Board: Role, Duties and Composition. Accepted for publication. https://doi.org/10.22495/cbv12i3art9 
Alves, S. (2014). The Effect of Board Independence on the Earnings Quality: Evidence from Portuguese Listed Companies. Australasian Accounting Business \& Finance Journal, 8(3), 23. https://doi.org/10.14453/aabfj.v8i3.3

Chen, G., Luo, S., Tang, Y., \& Tong, J. Y. (2015). Passing probation: Earnings management by interim CEOs and its effect on their promotion prospects. Academy of Management Journal,58(5), 1389-1418. https://doi.org/10.5465/amj.2013.0351

Chen, K., \& Liu, J. L. (2010). Earnings management, CEO domination, and growth opportunities: Evidence from Taiwan. International Journal of Public Information Systems, 6(1).

Davidson, R., Goodwin-Stewart, J., \& Kent, P. (2005). Internal governance structures and earnings management. Accounting and Finance, 45(2), 241-267. https://doi.org/10.1111/j.1467-629x.2004.00132.x

Doyle, J., W. G., \& McVay, S. (2007). Accrual quality and internal control over financial reporting. The Accounting Review, 44, 193-223.

Frankel, R., McVay, S., \& Soliman, M. (2011). 'Non-GAAP earnings and board independence'. Review of Accounting Studies, 16(4), 719-744. https://doi.org/10.1007/s11142-011-9166-3

Khalil, M., \& Ozkan, A. (2016). Board Independence, Audit Quality and Earnings Management: Evidence from Egypt. Journal of Emerging Market Finance. https://doi.org/10.1177/0972652715623701

Klein, A. (2002). Audit committee, board of director characteristics, and earnings management. Journal of accounting and economics, 33(3), 375-400. https://doi.org/10.1016/S0165-4101(02)00059-9

Liao, L., Luo, L., \& Tang, Q. (2015). Gender diversity, board independence, environmental committee and greenhouse gas disclosure. The British Accounting Review, 47(4), 409-424. https://doi.org/10.1016/j.bar.2014.01.002

Lin, F., \& Wu, S. F. (2015). Applying Digital Analysis to Investigate the Relationship between Corporate Governance and Earnings Management: An Empirical Analysis of Publicly Listed Companies in Taiwan. Contemporary Management Research, 11(3). https://doi.org/10.7903/cmr.13144

Lin, T., Hutchinson, M., \& Percy, M. (2015). Earnings management and the role of the audit committee: an investigation of the influence of cross-listing and go vernment officials on the audit committee. Journal of Management \& Governance, 19(1), 197-227. https://doi.org/10.1007/s10997-013-9284-3

Liu, J. (2012). Board monitoring, management contracting and earnings management: an evidence from ASX listed companies. International Journal of Economics and Finance, 4(12), 121. https://doi.org/10.5539/ijef.v4n12p121

Najjar, D. M. A. (2016). Do ownership Concentration and Leverage Influence Firms' Value? Evidence from Panel Data in Jordan. International Journal of Business and Management, 11(6), 262. https://doi.org/10.5539/ijbm.v11n6p262

Villiers, C., Naiker, V., \& van Staden, C. J. (2011). The effect of board characteristics on firm environmental performance. Journal of Management, 37(6), 1636-1663. https://doi.org/10.1177/0149206311411506

Wan Mohammad, W. M., Wasiuzzaman, S., \& Nik Salleh, N. M. Z. (2016). Board and audit committee effectiveness, ethnic diversification and earnings management: a study of the Malaysian manufacturing sector. Corporate Governance, 16(4), 726-746. https://doi.org/10.1108/CG-06-2015-0085

Xie, B., Davidson, W. N., \& DaDalt, P. J. (2003). Earnings management and corporate governance: the role of the board and the audit committee. Journal of corporate finance,9(3), 295-316. https://doi.org/10.1016/S0929-1199(02)00006-8

\section{Copyrights}

Copyright for this article is retained by the author(s), with first publication rights granted to the journal.

This is an open-access article distributed under the terms and conditions of the Creative Commons Attribution license (http://creativecommons.org/licenses/by/4.0/). 